\title{
Prevalence of non-carious cervical lesions and cervical dentinary hypersensitivity in undergraduate students
}

\author{
Prevalência de lesão cervical não cariosa e hipersensibilidade dentinária \\ cervical em estudantes de um curso de graduação
}

\author{
João Victor Dias CRISÓSTOMO ${ }^{a}$ (D), Bruna Oliveira BEZERRA ${ }^{b}$ (i), \\ Mariana Garcia da Ponte MELO ${ }^{b}$ (D) Polyanna Maria ROCHA-NOVAIS $^{a}$ (D), \\ Maria Denise Rodrigues de-MORAES ${ }^{a *}$ (i) \\ aUNIFOR - Universidade de Fortaleza, Mestrado Profissional em Odontologia, Fortaleza, CE, Brasil \\ bUNIFOR - Universidade de Fortaleza, Cirurgiã-dentista, Curso de Odontologia, Fortaleza, CE, Brasil
}

How to cite: Crisóstomo JVD, Bezerra BO, Melo MGP, Rocha-Novais PM, de-Moraes MDR. Prevalence of non-carious cervical lesions and cervical dentinary hypersensitivity in undergraduate students. Rev Odontol UNESP. 2021;50:e20210051. https://doi.org/10.1590/1807-2577.05121

\begin{abstract}
Resumo
Introdução: A lesão cervical não cariosa (LCNC) é uma doença bucal incidente na atualidade. Objetivo: realizar um estudo observacional e descritivo para avaliar fatores de risco associados às lesões cervicais não cariosas, hipersensibilidade dentinária cervical (HDC), recessão gengival (RG) e a relação entre essas condições em estudantes nos últimos anos de graduação em odontologia. Material e método: participaram 185 estudantes de odontologia do Ceará com média de 22,7 $\pm 2,3$ anos de idade. Preencheram um formulário do google docs e dois examinadores calibrados realizaram os exames para verificar a presença de LCNC, HDC e RG. Resultado: A presença de LCNC foi de $22,7 \%$, a de RG foi de $48,1 \%$ e de hipersensibilidade dentinária cervical de 8,6\%. 0 teste qui-quadrado com $\mathrm{p}<0,05 \%$, verificou correlação entre a presença de LCNC e a presença de recessão gengival e hipersensibilidade dentinária. Nos alunos do último ano, $25 \%$ apresentaram LCNC, dos quais $14 \%$ consideravam-se estressados. Não houve associação entre as variáveis bruxismo e estresse $(p=0,529)$, bruxismo e ano do curso da graduação $(p=0,716)$, bem como não foi observada associação de estresse e ano do curso ( $p=0,397)$. Não houve correlação da LCNC e bruxismo, sintomatologia muscular, hábitos parafuncionais e disfunção temporo-mandibular (DTM). Dos alunos que relataram utilizar drogas lícitas e ilícitas, 10,8\% apresentaram LCNC. Conclusão: A LCNC, RG e HD apresentaram correlação no grupo de estudantes dos dois últimos anos de um curso de graduação em odontologia do Ceará.
\end{abstract}

Descritores: Atrito dentário excessivo; abrasão dentária; erosão dentária.

\begin{abstract}
Introduction: The non-carious cervical lesion (NCCL) is currently a common oral disease. Objective: This observational and descriptive study aimed to assess risk factors associated with non-carious cervical lesions, cervical dentin hypersensitivity (CDH), gingival recession (GR) and the relationship between these conditions in students in the last years of undergraduate dentistry. Material and method: One hundred eighty-five dentistry students from a private college in Ceará with an average of $22.7 \pm 2.3$ years participated by filling out a google docs form. Two calibrated examiners performed the exams to verify the presence of NCCL, CDH and RG. Result: The presence of NCCL was $22.7 \%$, GR was $48.1 \%$ and cervical dentin hypersensitivity $8.6 \%$. The chi-square test with $\mathrm{p}<0.05 \%$ verified a correlation between the presence of NCCL and the presence of GR and CDH. 25\% of students had NCCL and 14\% considered themselves stressed. There was no association between the variables bruxism and stress ( $\mathrm{p}=0.529)$, bruxism and year of graduation course ( $p=0.716)$, as well as no association between stress and year of course $(p=0.397)$ was observed. There were no correlations between NCCL and bruxism, muscle symptoms, parafunctional habits and temporomandibular dysfunction. $10.8 \%$ of students who reported using legal and illegal drugs had
\end{abstract}


NCCL. Conclusion: The NCCL, GR and CDH were correlated in the group of students in the last two years of an undergraduate dentistry course in Ceará.

Descriptors: Excessive dental friction; dental abrasion; tooth erosion.

\section{INTRODUCTION}

The improvement in the prevention of dental caries disease and the population's understanding of the importance of preserving teeth demonstrates a new reality seen by dentists in dental offices ${ }^{1}$. Teeth get old, and suffer from various factors over the years. Wear in the cervical region of its mineralized structure, appearing the so-called non-carious cervical lesions (NCCL). These are characterized by the loss of dental tissue, with no decay, and are considered to be contemporary multifactorial changes and directly linked to the patients' lifestyle habits ${ }^{1,2}$.

The etiology of NCCL can be associated with factors such as tightening, bruxism, inadequate brushing techniques and biocorrosive action due to frequent access to corrosive environments, acidic diets, reflux and digestive system diseases ${ }^{3}$. The popularization of acidic and detoxifying diets and supplements vitamins, has increased the exposure of teeth to acids. Athletes who have exposure to the pool without adequate acidity treatment, individuals who work in industries, winemakers, among others, are risk groups for these diseases 4 .

Due to these factors, the tooth is deformed and micro-ruptures in the hydroxyapatite crystals occur in the stress area. Thus, spaces filled with water molecules are created preventing the formation of new chemical bonds between the crystals, thus making the crystal structures vulnerable to chemical and physical action generated by physiological factors or mechanical processes ${ }^{5}$. In this sense, the appearance of NCCL varies from shallow depressions with a large disk shape to large cone-shaped defects. The cavity floor can be flat, smooth, shiny or sharply sloping. NCNC are predominantly found in premolars and molars, with decreasing occurrence in anterior teeth and are often located on the buccal surface ${ }^{5}$.

The evolution of NCCL is not only dependent on these factors, but on the quantity, frequency, location, duration and orientation of eccentric occlusal forces. The highest prevalence is in premolars due to biomechanics, considering that the cervical constriction they present creates an area of greater concentration of stress. Another factor that directly influences is the smaller bone thickness found on the buccal surface of these teeth, making them more susceptible to the formation of lesions ${ }^{6}$. The concentration of stress resulting from occlusal loading, mainly caused by parafunctions and poorly completed orthodontic treatment, can lead to the resultant of compression, tension, flexion and shear forces in more friable regions of the tooth, such as the cervical region.

Studies have shown that occlusal trauma, defined as a tissue alteration caused by masticatory forces of significant magnitude and direction, arising from malocclusion and/or parafunctional habits, is one of the etiological factors of NCCL. Masticatory forces applied outside the longitudinal dental axis normally generate lateral forces that are dissipated mainly at the cementoenamel junction ${ }^{5}$. Bruxism, for example, is a parafunctional habit characterized by clenching and/or grinding of teeth, capable of posing a danger to integrity of the structures of the stomatognathic system $^{4}$. In addition, during mastication we have complex masticatory efforts, where during the simple act of chewing, forces are directly influenced by the anatomical variation of the teeth, the anatomy of posterior teeth with inclined slopes, the most variable movements jaws and their contact points in different positions, which, depending on the tooth touched, can generate different force vectors.

Thus, to prevent the disease, it is necessary to know its etiology and diagnose it in advance, reducing the consequences of bad habits that degrade teeth on a daily basis. The presence of modifying factors, such as saliva, tongue action, microstructure, mobility and positional prominence are determinant in the evolution of the disease ${ }^{7}$. However, when these lesions 
progress, it can compromise the vitality of the pulp and the structural integrity of the teeth as well as causing discomfort due to hypersensitivity and aesthetic problems ${ }^{1,2}$. In many patients, NCCLs are the main cause of the sensitivity and discomfort that result from dentin exposure ${ }^{5}$.

Dentin hypersensitivity is a challenging condition for treatment in clinical dental practice and can be defined as a short acute pain that appears on exposed dentin in response to thermal, tactile, osmotic, chemical or evaporative stimuli that cannot be attributed to any other form of dental defect or pathology. The higher prevalence of CDH may suggest an association with some specific clinical conditions, for example, gingival recession, non-carious cervical lesions and tooth wear8.

NCCLs were found to be increasingly prevalent with age ${ }^{1,2}$. However, young undergraduate students tend to have an irregular sleep pattern due to the accumulation of curricular activities and exposure to stressful situations that can interfere with their quality of life. Such situations can lead to both centric and eccentric bruxism. Such parafunctions are related to an early wear of teeth. Tooth wear is a cause for concern as it is not possible to identify a single specific factor that influences the prevalence of tooth wear facets in younger people 4 .

Studies in the literature have described the relationship between poor sleep quality and tooth wear in some individuals, especially those engaged in professions that are exposed to constant pressure and stress. It is speculated that about 7 out of 10 people have cervical injuries, associated with food, hygiene, stress, gastrointestinal problems, sleep and also the practice of sports9.

Therefore, even with the growing increase in the appearance of non-carious cervical lesions and other diseases addressed, there is still not enough data relating a population of higher education students who present several risk factors for the development of the diseases. Thus, the objective of the present work is to carry out an observational and descriptive study to assess the risk factors associated with non-carious cervical lesions (NCCL), cervical dentin hypersensitivity (CDH) and gingival recession (GR) in students in the last years of the course. degree in dentistry from a university in Ceará.

\section{MATERIAL AND METHOD}

The research protocol for this study was firstly submitted to the Ethics Committee of the University of Fortaleza, having been approved, under opinion number 3,152,519. Upon approval, the investigation details and procedures were explained to each participant. 185 undergraduate students from a private dental school (University of Fortaleza-UNIFOR) with a mean age of $22.7 \pm 2.3$ years were examined. A Google docs questionnaire was used as a data collection instrument. Clinical examination was used to verify the presence of NCCL, gingival recession (GR) and cervical dentin hypersensitivity (CDH).

\section{Study Design}

This is an observational and descriptive study. The sample consisted of students from the last two years of the Graduate Course in Dentistry at the University of Fortaleza, located in the city of Fortaleza, Ceará, Brazil. The questionnaire included: name of the participant, age, semester in which they were attending and the type of toothbrushing according to self-perception. Participants were also asked about the presence of parafunctional habits, presence of bruxism or clenching, whether they considered themselves stressed, whether they were undergoing or had already undergone any treatment for anxiety, whether they had gastroesophageal diseases, whether they were using legal or illegal drugs, what type of toothbrush and toothpaste they used and a dental evaluation was performed. Then, the clinical examination was performed, in which the examiner assessed the presence of NCCL, HD and GR, isolated or combined. In cases where 
there was the presence of NCCL, it was documented which tooth was affected, as well as the size and depth of the lesions.

\section{Proposed Methodology}

This research was carried out at the University of Fortaleza, from February 2019 to March 2020, with 185 students from the last two years of the Dentistry course at the University of Fortaleza.

\section{Inclusion Criteria}

A convenience sample was carried out, in which participants who were enrolled in subjects in the last two years of the undergraduate course at the University of Fortaleza, were over 18 years old and who agreed to fill out the Informed Consent Term, were included in the research. The volunteers answered the questionnaire and underwent clinical examination to analyze the presence of non-carious cervical lesion (NCNC), dentin hypersensitivity (HD) and gingival recession (GR).

\section{Exclusion Criteria}

Students who were in a student regime that prevented them from attending the semester's activities during the period of data collection were excluded from the research. In addition, students who refused to participate in the research were excluded. Among 251 students enrolled in the last two years of graduation, 30 were not present at the time of taking the exam, 10 did not accept to participate and in 26 it was not possible to take the exam because the quarantine was started due to the Covid-19 pandemic, resulting in in the 185 students who participated in the survey.

\section{Collection Procedures}

Participants were recruited through written notices at specific locations, such as flannelgraphs and academic centers. Students enrolled in the last years of the undergraduate course at the University of Fortaleza were invited to volunteer. No student was directly or indirectly affected when deciding to participate in the research. These students participated in filling out an anamnesis and questionnaire form (attached). In an outpatient setting of a dental office, all volunteers underwent a clinical examination using good direct and indirect lighting, a clinical mirror, WHO and Williams periodontal dream and using the triple syringe air jet, one foot away.

\section{Data Analysis}

The data obtained through the questionnaire were tabulated in a Microsoft Excel 2016 spreadsheet. The characterization of the participants was covered by a descriptive analysis of qualitative variables through tables. In order to assess the association between the tested variables, Pearson's chi-square test was used. Data were analyzed using SPSS (Statistical Package for Social Sciences) version 20.0, with a significance level of 5\%. 


\section{RESULT}

The results obtained in this study can be broadly seen in Table 1 .

Table 1. The Chi-square test results, $p<0.05 \%$

\begin{tabular}{|c|c|c|c|c|c|}
\hline \multirow{3}{*}{ Variables } & \multicolumn{4}{|c|}{ NCCL } & \multirow{3}{*}{$\mathbf{p}^{*}$} \\
\hline & \multicolumn{2}{|c|}{ YES } & \multicolumn{2}{|c|}{ NO } & \\
\hline & $\mathbf{n}$ & $\%$ & $\mathbf{n}$ & $\%$ & \\
\hline \multicolumn{6}{|l|}{ Sex } \\
\hline Masculine & 17 & 9.2 & 46 & 24.9 & 0.318 \\
\hline Feminine & 25 & 13.5 & 97 & 52.4 & \\
\hline \multicolumn{6}{|c|}{ Hypersensitivity Presence } \\
\hline NO & 27 & 14.6 & 142 & 76.8 & $<0.001 *$ \\
\hline YES & 15 & 8.1 & 1 & 0.5 & \\
\hline \multicolumn{6}{|l|}{ Recession } \\
\hline NO & 0 & 0.0 & 96 & 51.9 & $<0.001$ * \\
\hline YES & 42 & 22.7 & 47 & 25.4 & \\
\hline \multicolumn{6}{|c|}{ Temporomandibular dysfunction } \\
\hline NO & 21 & 11.4 & 79 & 42.7 & 0.549 \\
\hline YES & 21 & 11.4 & 64 & 34.6 & \\
\hline \multicolumn{6}{|c|}{ Muscle Symptomatology } \\
\hline NO & 29 & 15.7 & 103 & 55.7 & 0.707 \\
\hline YES & 13 & 7.0 & 40 & 21.6 & \\
\hline \multicolumn{6}{|c|}{ Parafunctional Habits } \\
\hline NO & 23 & 12.4 & 76 & 41.1 & 0.854 \\
\hline YES & 19 & 10.3 & 67 & 36.2 & \\
\hline \multicolumn{6}{|l|}{ Bruxism } \\
\hline NO & 24 & 13.0 & 92 & 49.7 & 0.397 \\
\hline YES & 18 & 9.7 & 51 & 27.6 & \\
\hline \multicolumn{6}{|l|}{ Stress } \\
\hline NO & 16 & 8.6 & 51 & 27.6 & 0.773 \\
\hline YES & 26 & 14.1 & 92 & 49.7 & \\
\hline \multicolumn{6}{|c|}{ Anxiety Treatment } \\
\hline NO & 28 & 15.1 & 113 & 61.1 & 0.098 \\
\hline YES & 14 & 7.6 & 30 & 16.2 & \\
\hline \multicolumn{6}{|l|}{ Drugs } \\
\hline NO & 22 & 11.9 & 55 & 29.7 & 0.108 \\
\hline YES & 20 & 10.8 & 88 & 47.6 & \\
\hline \multicolumn{6}{|l|}{ Age } \\
\hline $18-27$ & 36 & 20.5 & 141 & 79.7 & $<0.001^{*}$ \\
\hline $28-37$ & 6 & 75 & 2 & 25 & \\
\hline \multicolumn{6}{|l|}{ Course Year } \\
\hline Penultimate & 18 & 20.2 & 71 & 79.8 & 0.439 \\
\hline Last & 24 & 25 & 72 & 75 & \\
\hline \multicolumn{6}{|c|}{ Brushing technique } \\
\hline Fones & 35 & 18.9 & 113 & 61.1 & 0.121 \\
\hline Bass & 6 & 3.2 & 30 & 16.2 & \\
\hline Others & 1 & 0.5 & 0 & 0.0 & \\
\hline
\end{tabular}

The sample of the group of patients with the presence of NCNCs had the most prevalent age in the range between 28 and 37 years. The prevalence of NCCL was $22.7 \%$ in this community of 
students, with the distribution of lesions between the teeth being $2 \%$ in the central incisor, $7 \%$ in the lateral incisor, $8 \%$ canine, $55 \%$ in the premolars, $25 \%$ in the molars. The Prevalence of GR was $48.1 \%$ in this population.

The Chi-square test with $\mathrm{p}<0.05 \%$ verified that there was a correlation between the presence of NCCL and the variables presence of gingival recession and dentinal hypersensitivity. Among the volunteers in the survey who were attending the last year, $25 \%$ had the presence of NCCL, while students from the penultimate semester only $20.2 \%$. Fourteen percent of students who had NCCL consider themselves stressed, although only $7 \%$ have undergone some type of treatment for anxiety.

There was no association between the variables Bruxism and stress ( $\mathrm{p}=0.529)$, bruxism and year of graduation course ( $\mathrm{p}=0.716)$, as well as no association between stress variables and year of course $(p=0.397)$. No correlation was found between the presence of NCCL and bruxism, muscle symptoms, parafunctional habits and TMD. Also, students who reported using legal and illegal drugs did not show a prevalence of NCCL. The questions semesters, year of the course, brushing technique, and treatment for anxiety did not show any correlation with the prevalence of NCCL.

\section{DISCUSSION}

This research aimed to study non-carious cervical lesions (NCCL) and different factors that may contribute to their development. As is known, such lesions have a multifactorial etiology, and it is not possible to point out a single factor as responsible for their appearance $5,7-14$.

The present study was carried out in dentistry students at the University of Fortaleza, Ceará-Brazil, attending the last two years of graduation, where 177 students were between 18-27 years old and 8 students were between $28-37$ years old. Of these $177,20.5 \%$ had NCCL and of the 8 students aged 28 to 37 years, $75 \%$ had these lesions. A previous study showed that the prevalence of NCCLs occurs in up to $85 \%$ of individuals, and that it increases with age 16 . As demonstrated in this research, there was no correlation between young adults and the prevalence of non-carious cervical lesions. It can be observed that students aged between 28-37 years had a higher prevalence of NCCL, corroborating previous studies, in which age was a determining factor for these lesions, since older populations were probably exposed to the factors etiological for longer than younger ones and in addition to presenting a greater severity (size) of these lesions, 5,8,9,15.

In non-carious cervical lesions, there is a loss of tooth structure in the cervical region of the teeth, which can cause damage to aesthetics and hypersensitivity, as reported by Telles et al. ${ }^{2}$ and Nascimento et al. ${ }^{8}$. The dentinal tubules can be exposed as a result of enamel loss by friction, abrasion, erosion or abfraction, generating a short, sharp pain that arises from the exposed dentin in response to stimuli ${ }^{16}$. This fact corroborates the present study, in which, in relation to the aspects that were analyzed, it can be seen that of the students who presented dentinal hypersensitivity, only one did not have a non-carious cervical lesion. Among patients from the specialized clinic who present hypersensitivity, when compared to other groups, it may indicate the relationship of this condition with gingival recession, non-carious cervical lesions and tooth wear ${ }^{17}$. Young adults are more susceptible to the development of hypersensitivity, considering the habits and lifestyle that lead, for example, to an acidic diet and parafunctional habits ${ }^{9,18}$.

When NCCL involves the root, it is commonly associated with gingival recession ${ }^{19}$. As described by Cunha-Cruz et al. ${ }^{18}$, gingival recession can cause dentin exposure and loss of cementum from tooth roots, more frequently in canines and premolars. Such recession can be stimulated by aggressive or frequent brushing and periodontal treatment. In addition, occlusal overload is a common etiological factor of NCCLs and gingival recession ${ }^{5}$. In the present study, we found that there was a relationship between gingival recession and non-carious cervical lesions, considering that of the 42 students who were diagnosed with NCCL, all they also had gingival 
recession. However, there is some difficulty in differentiating early shallow NCCLs and persistent gingival recession, compromising the diagnosis and resulting in greater or lesser prevalence. These lacks of standardized definitions strengthen the bias between studies ${ }^{5,9}$.

In the present study, it was found that the highest prevalence of NCCLs is found in premolars $(55 \%)$ and molars $(25 \%)$, with decreasing occurrence in anterior, central incisor $(2 \%)$, lateral incisor $(7 \%)$ and canine (8\%), which confirms the findings in other studies. $2,4,7,17$ This prevalence is probably due to the resulting forces that are applied outside the longitudinal axis of the teeth and that normally generate lateral forces that are dissipated first in the teeth cemento-enamel junction ${ }^{2,5}$. In addition, the position of teeth in the arch also has an important effect on functional and parafunctional forces. According to Brandini etal. 5 the first premolars are almost perpendicular to the alveolar bone, but the premolar cusps generate an inclined force in contact with the antagonist teeth. This effect tends to cause the cusps to bend during lateral movements of the mandible with teeth in contact, causing cervical stress and contributing to the development of fractures. Furthermore, studies have reported that the position of the occlusal load modifies the intensity of stress concentration in the cervical regions. Loads applied obliquely along the long axis of the tooth can promote an increase in stress in the cervical region and are related to the formation and progression of NCCLs ${ }^{16}$. Also, the presence of traumatic dental occlusion is considered an important factor in the occurrence of these injuries ${ }^{13}$.

According to Soares et al. ${ }^{4}$ in their study, $90 \%$ of participants who were diagnosed with bruxism reported symptoms of stress. Apparently, stress plays an important role in triggering and maintaining bruxism, which is one of the predisposing factors for the onset of non-carious cervical lesions $2,4,5,16$. Stress related to undergraduate students is explained by Soares et al. ${ }^{4}$, due to the irregular sleep pattern and the accumulation of extracurricular activities that can be conflicting, exposing undergraduate students to various stressful situations. Another study corroborates this information, where after an analysis of the data obtained, it was concluded that the type of profession of an individual influences the quality of sleep and the presence of wear and tear facets ${ }^{10}$. However, in the present study, there was no association of stress $(p=0.529)$ related to the penultimate and last year of graduation with the appearance of NCCL s, in addition, no correlation was found with muscle symptoms, parafunctional habits and TMD. Probably, the fact that no correlation was found between these injuries with stress and these reported temporomandibular symptoms can be justified due to the average age of 22 years, demonstrating that, in addition to the factors presented, a fatigue component would be necessary in the formation of NCCLs associated with occlusal interferences or any event that alters dental occlusion, because, as they are young people, these factors, even if they exist, did not have enough time to cause wear. These events change the pattern of stress distribution in the cervical region and can lead to a weakening of the continuity between the structures, generating an NCCL ${ }^{16}$. Furthermore, it is argued that an occlusal load that is far from the site of the cervical defect cannot be considered cause of these injuries ${ }^{8}$. The main difficulties in establishing a relationship between these injuries and temporomandibular symptoms are accurate measurements of volumetric loss of cervical injuries and direct measurements of occlusal force and the path of excursion ${ }^{20}$.

In the study carried out by Serra-Negra et al. ${ }^{10}$, no association was observed between alcohol consumption and the presence of wear facets, which is in agreement with the present study, where there was also no relationship between NCCL and the use of legal and illegal drugs. However, there are studies that show the prevalence of tooth erosion and tooth wear in patients with alcohol dependence and individuals with high wine consumption. Individuals who abuse alcohol are considered populations at risk for dental erosion, taking into account intrinsic factors such as gastroesophageal reflux and persistent vomiting that excessive consumption of such drinks can cause, in addition to extrinsic sources (depending on the type and frequency of consumption alcoholic). The erosive potential results from its low pH (2.9 to 5.1) and its low content of calcium and phosphate ions ${ }^{21}$. However, this risk does not only result from this potential, but also from the high comorbidity between alcohol, depression and smoking ${ }^{10}$. 


\section{CONCLUSION}

Given the limitations of this observational study, it can be concluded that NCCL, GR and CDH were correlated with each other in the group of students in the last two years of an undergraduate dentistry course in Ceará, but they did not show a correlation between factors such as stress and temporomandibular dysfunction.

\section{REFERENCES}

1. Teixeira DNR, Zeola LF, Machado AC, Gomes RR, Souza PG, Mendes DC, et al. Relationship between noncarious cervical lesions, cervical dentin hypersensitivity, gingival recession, and associated risk factors: a cross-sectional study. J Dent. 2018 Sep;76:93-7. http://dx.doi.org/10.1016/j.jdent.2018.06.017. PMid:29940290.

2. Telles D, Pegoraro LF, Pereira JC. Incidence of noncarious cervical lesions and their relation to the presence of wear facets. J Esthet Restor Dent. 2006;18(4):178-83. http://dx.doi.org/10.1111/j.17088240.2006.00015.x. PMid:16911416.

3. Grippo JO, Simring M, Schreiner S. Attrition, abrasion, corrosion and abfraction revisited: a new perspective on tooth surface lesions. J Am Dent Assoc. 2004 Aug;135(8):1109-18. http://dx.doi.org/10.14219/jada.archive.2004.0369. PMid:15387049.

4. Soares LG, Costa IR, Brum JS Jr, Cerqueira WSB, Oliveira ES, Oliveira DWD, et al. Prevalence of bruxism in undergraduate students. Cranio. 2017 Sep;35(5):298-303. http://dx.doi.org/10.1080/08869634.2016.1218671. PMid:27684574.

5. Brandini DA, Trevisan CL, Panzarini SR, Padrini D. Clinical evaluation of the association between noncarious cervical lesions and occlusal forces. J Prosthet Dent. 2012 Nov;108(5):298-303. http://dx.doi.org/10.1016/S0022-3913(12)60180-2. PMid:23107237.

6. Soares PV. Lesões cervicais não cariosas e hipersensibilidade dentinária: protocolos reabilitadores e estéticos. Uberlândia: FOUFU; 2014.16p.

7. Grippo JO, Simring M, Coleman TA. Abfraction, abrasion, biocorrosion, and the enigma of noncarious cervical lesions: a 20-year perspective. J Esthet Restor Dent. 2012 Feb;24(1):10-23. http://dx.doi.org/10.1111/j.1708-8240.2011.00487.x. PMid:22296690.

8. Nascimento M, Dilbone D, Pereira P, Geraldeli S, Delgado A, Duarte W. Abfraction lesions: etiology, diagnosis, and treatment options. Clin Cosmet Investig Dent. 2016 May;8:79-87. http://dx.doi.org/10.2147/CCIDE.S63465.

9. Teixeira DNR, Thomas RZ, Soares PV, Cune MS, Gresnigt MMM, Slot DE. Prevalence of noncarious cervical lesions among adults: a systematic review. J Dent. 2020 Apr;95:103285. http://dx.doi.org/10.1016/j.jdent.2020.103285. PMid:32006668.

10. Serra-Negra JM, Aquino MS, Silva MES, Abreu MH, Silveira RR. Tooth wear and sleep quality: a study of police officers and non-police officers. Cranio. 2018 Jan;36(1):6-10. http://dx.doi.org/10.1080/08869634.2016.1263275. PMid:27927084.

11. Nguyen C, Ranjitkar S, Kaidonis JA, Townsend GC. A qualitative assessment of non-carious cervical lesions in extracted human teeth. Aust Dent J. 2008 Mar;53(1):46-51. http://dx.doi.org/10.1111/j.1834-7819.2007.00009.x. PMid:18304241.

12. Wada I, Shimada Y, Ikeda M, Sadr A, Nakashima S, Tagami J, et al. Clinical assessment of non carious cervical lesion using swept-source optical coherence tomography. J Biophotonics. 2015 Oct;8(10):84654. http://dx.doi.org/10.1002/jbio.201400113. PMid:25504772.

13. Soares PV, Machado AC, Zeola LF, Souza PG, Galvão AM, Montes TC, et al. Loading and composite restoration assessment of various non-carious cervical lesions morphologies - 3D finite element analysis. Aust Dent J. 2015 Sep;60(3):309-16. http://dx.doi.org/10.1111/adj.12233. PMid:25312697. 
14. Sugita I, Nakashima S, Ikeda A, Burrow MF, Nikaido T, Kubo S, et al. A pilot study to assess the morphology and progression of non-carious cervical lesions. J Dent. 2017 Feb;57:51-6. http://dx.doi.org/10.1016/j.jdent.2016.12.004. PMid:27956017.

15. Igarashi Y, Yoshida S, Kanazawa E. The prevalence and morphological types of non-carious cervical lesions (NCCL) in a contemporary sample of people. Odontology. 2017 Oct;105(4):443-52. http://dx.doi.org/10.1007/s10266-017-0300-y. PMid:28275876.

16. Zeola LF, Pereira F, Galvão AM, Montes T, Sousa SC, Teixeira DNR, et al. Influence of non carious cervical lesions depth, loading point application and restoration on stress distribution pattern in lower remolars: a 2d finite element analysis. Biosci J. 2015 Mar;31(2):648-56. http://dx.doi.org/10.14393/BJ-v31n2a2015-27837.

17. Borcic J, Anic I, Urek MM, Ferreri S. The prevalence of non-carious cervical lesions in permanent dentition. J Oral Rehabil. 2004 Feb;31(2):117-23. http://dx.doi.org/10.1046/j.0305182X.2003.01223.x. PMid:15009594.

18. Cunha-Cruz J, Wataha JC, Heaton LJ, Rothen M, Sobieraj M, Scott J, et al. The prevalence of dentin hypersensitivity in general dental practices in the northwest United States. J Am Dent Assoc. 2013 Mar;144(3):288-96. http://dx.doi.org/10.14219/jada.archive.2013.0116. PMid:23449905.

19. Zucchelli G, Gori G, Mele M, Stefanini M, Mazzotti C, Marzadori M, et al. Non-carious cervical lesions associated with gingival recessions: a decision-making process. J Periodontol. 2011 Dec;82(12):171324. http://dx.doi.org/10.1902/jop.2011.110080. PMid:21542735.

20. Pintado MR, Delong R, Ko CC, Sakaguchi RL, Douglas WH. Correlation of noncarious cervical lesion size and occlusal wear in a single adult over a 14-year time span. J Prosthet Dent. 2000 0ct;84(4):436-43. http://dx.doi.org/10.1067/mpr.2000.109477. PMid:11044852.

21. Teixeira L, Manso MC, Manarte-Monteiro P. Erosive tooth wear status of institutionalized alcoholic patients under rehabilitation therapy in the north of Portugal. Clin Oral Investig. 2017 Apr;21(3):80919. http://dx.doi.org/10.1007/s00784-016-1823-2. PMid:27121798.

\section{CONFLICTS OF INTERESTS}

The authors declare no conflicts of interest.

\section{${ }^{*}$ CORRESPONDING AUTHOR}

Maria Denise Rodrigues de Moraes, UNIFOR - Universidade de Fortaleza, Mestrado Profissional em Odontologia, Rua Israel Bezerra, 1033, Apto 501, 60135-460 Fortaleza - CE, Brasil, e-mail: denisermoraes@gmail.com

Received: October 21, 2021

Accepted: November 2, 2021 